\title{
Genital infection by Aerococcus viridans in a captive african elephant (Loxodonta africana)
}

\author{
Salene Angelini Colombo ${ }^{1}$ B Brendhal Almeida Silva ${ }^{1}$ Sandra Yuliet Marín Gómez ${ }^{1}$ (D) \\ Renato de Lima Santos ${ }^{2}$ Herlandes Penha Tinoco ${ }^{3}$ (D) Carlyle Mendes Coelho ${ }^{3}$ (D) \\ Junia Pacheco Teixera1 ${ }^{1}$ Carlos Augusto Gomes Leal ${ }^{1 *}(\mathbb{D}$
}

\footnotetext{
${ }^{1}$ Departamento de Medicina Veterinária Preventiva, Escola de Veterinária da Universidade Federal de Minas Gerais, Universidade Federal de Minas Gerais (UFMG), 31270-901, Belo Horizonte, MG, Brasil. E-mail: carlosleal@vet.ufmg.br. "Corresponding author.

${ }^{2}$ Departamento de Clínica e Cirurgia Veterinárias, Escola de Veterinária da Universidade Federal de Minas Gerais (UFMG), Belo Horizonte, MG, Brasil.

${ }^{3}$ Fundação de Parques Municipais e Zoobotânica, Belo Horizonte, MG, Brasil.
}

\begin{abstract}
Aerococcus viridans is an emerging pathogen for humans and livestock animals, mainly associated with genitourinary infections cases. Its occurrence in wild mammals has never been reported. The aim of this study was to determine the etiological agent associated with clinical a case of a genital infection in a female African elephant (Loxodonta africana). Phylogenetic analysis and antimicrobial susceptibility profile of the isolate were also addressed. The animal presented frequent cases of genital infection with intermittent white secretion. Purulent secretion was sampled and submitted to bacteriological exam. The isolate obtained was thus identified by phenotypic and molecular methods as A. viridans and was found to be similar to human pathogenic isolates in BLASTn and phylogenetic analysis. The isolate was sensitive to almost all antimicrobials evaluated, presenting resistance to ciprofloxacin and norfloxacin. This is the first report of occurrence of A. viridans infection in the genital tract of an African elephant.

Key words: Aerococcus viridans, zoo mammal, genital infection, MALDI-Tof, 16S rRNA sequencing.
\end{abstract}

Infecção genital por Aerococcus viridans em um elefante africano em cativeiro (Loxodonta africana)

RESUMO: Aerococcus viridans é um patógeno emergente para seres humanos e animais de produção, principalmente associado a casos de infecções geniturinárias. Sua ocorrência em mamíferos selvagens nunca foi relatada. $O$ objetivo deste estudo foi determinar o agente etiológico associado a um caso clínico de infecção genital em uma fêmea de elefante africano (Loxodonta africana). Análises filogenéticas e perfil de susceptibilidade antimicrobiana do isolado também foram avaliados. $O$ animal apresentou casos frequentes de infecção genital com eliminação de secreção branca intermitente. A secreção purulenta foi coletada e submetida a exame bacteriológico. O isolado obtido foi identificado por métodos fenotipicos e moleculares como A. viridans e apresentou alta similaridade a isolados humanos patogênicos nas análises de BLASTn e filogenética. O isolado foi sensivel a quase todos os antimicrobianos avaliados, apresentando resistência à ciprofloxacina e norfloxacina. Este é o primeiro relato de ocorrência de infecção por A. viridans no trato genital de elefante africano.

Palavras-chave: Aerococcus viridans, mamífero zoo, infecção genital, MALDI-TOF, sequenciamento $16 S$ rRNA.

Aerococcus viridans is a gram-positive bacterium first described in 1953, being the first characterized species of the genus Aerococcus (WILLIAMS et al., 1953). Later reports recognized the pathogenic potential of the species to humans, causing severe systemic conditions such as meningitis (NATHAVITHARANA et al., 1983), endocarditis (PIEN et al., 1984) osteomyelitis and septic arthritis (TAYLOR et al., 1985).

Recently, this microorganism has emerged as a pathogen of humans and livestock, being mainly associated with acute infections in the genitourinary tract of these hosts (LEITE et al., 2010; TOHNO et al.,
2014), as well as related to sepsis in pigs (MARTÍN et al., 2007), subclinical mastitis (LIU et al., 2015) and septicemia in human neonates (accession number Genbank MG576151.1).

Its occurrence in wild mammals has never been reported. It is known that there is a correlation between the maintenance of wild animals in captivity and the increase in the occurrence of diseases due to the continued exposure of these animals to potentially pathogenic microorganisms. Alerting the relevance of the zoonotic character of some of these agents, there are several reports of zoonoses involving wild and domestic animals, as exemplified by the occurrence of 
Toxoplasma gondii in captive carnivores (FERREIRA et al., 2018). The pathogenesis of infection by the genus Aerococcus in different hosts is still poorly understood, and fundamental issues such as the normal habitat of pathogenic species and the mode of agent-host interaction are not well known. Recent human cases have shown a change in the virulence profile of this pathogen, in which $A$. viridans was able to cause serious diseases, even in immunocompetent hosts (YADAV et al., 2018; PARREY et al., 2016). The cases stood out for the acute aspect in the course of the disease. In addition, in one of the cases the transmission of the agent was indicated through the consumption of lobster affected by gaffekia, a disease caused by $A$. viridans var. homari, suggesting a new transmission route never documented before (YADAV et al., 2018). The aim of this study was to determine the etiology of acute genital tract infection in a female African elephant (Loxodonta africana). Additionally, phylogenetic analyzes and antimicrobial susceptibility profile of the isolate are also addressed.

The elephant had been subjected to surgery in the vestibular region between the vulva and the vagina in the early 1980s. The surgical procedure resulted in a fistula for external communication of the reproductive and urethra. The animal had no signs of dysuria after the surgery. Despite the fistula, the female had two normal gestations and parturitions. Local disinfection was routinely performed with antiseptics and repellent ointments. The animal has been housed at the Belo Horizonte Zoological Garden since 1976, along with another female and an adult male, separated from the females for reproductive control. The animal presented frequent cases of genitourinary infection with intermittent white secretion. During daily management, purulent vulvar secretion was observed. Samples were collected directly from the vaginal canal using a sterile swab and immediately transported to the laboratory for bacteriological examination.

The sample was streaked onto $5 \%$ defibrinated sheep's blood and incubated under aerobic and anaerobic conditions at $37{ }^{\circ} \mathrm{C}$ for 48 h. Small, non-pigmented, pointy colonies with alpha-hemolytic activity were isolated. The isolate was characterized by Gram staining, catalase and oxidase tests. Identification of the isolate was performed by API 20 Strep $^{\circledR}$ (Biomerieux, France) according to the manufacturer's recommendations. Bacterial species was confirmed via MALDI-TOF MS analysis performed using a MicroFlex $^{\circledR}$ LT mass spectrometer (Bruker Daltonics, Bremen, Germany). The parameters for mass range detection and identification score criteria used were those recommended by the manufacturer.

DNA extraction was performed using the Maxwell ${ }^{\circledR} 16$ automatic extractor Promega (Madison, Wisconsin, USA) according to the manufacturer's specifications. Extracted DNA was quantified using

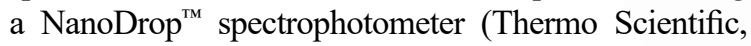
Wilmington, USA) and stored at $-80^{\circ} \mathrm{C}$ until further use.

The 16S rRNA gene was amplified by a PCR according to the method described in the literature (FOX et al., 1995). PCR products were purified using the Agencourt ${ }^{\circledR}$ AMPure $^{\circledR}$ XP Reagent Beckman Coulter (Brea, California, EUA). Sequencing reactions were conducted using a BigDye $^{\mathrm{TM}}$ Terminator Cycle sequencing kit Applied Biosystems (Foster City, California, EUA) and run on an ABI 3500 Genetic Analyzer Life Technologies (Carlsbad, California, EUA).

The 16S rRNA sequence was subjected to BLASTn (http://ncbi.nlm.nih.gov) analysis. Sequence identity $>98 \%$ was used as the criterion for species identification. The sequence of the isolates was aligned in BioEdit (HALL, 1999) using CLUSTAL W (THOMPSON et al., 1994) with sequences of the strains $A$. viridans isolates and species of the genus Aerococcus with validly published names and related taxa in GenBank.

The genetic distances matrix was obtained using Kimura's two-parameter model (KIMURA, 1980), and an evolutionary tree was created using the neighbor-joining method (SAITOU, 1987) with Mega7 (KUMAR et al., 2016).

Antimicrobial susceptibility pattern of the isolate was evaluated by disc diffusion methodology performed according to The European Committee on Antimicrobial Susceptibility Testing ${ }^{\circledR}$ (EUCAST) manual on antimicrobial susceptibility testing for fastidious organisms ${ }^{3}$. The following antibiotics were tested: ampicillin $(10 \mu \mathrm{g})$, ceftriaxone $(30 \mu \mathrm{g})$, ciprofloxacin $(5 \mu \mathrm{g})$, meropenem $(10 \mu \mathrm{g})$, norfloxacin $(10 \mu \mathrm{g})$, penicillin $\mathrm{G}(10 \mu \mathrm{g})$ and vancomycin $(30$ $\mu \mathrm{g})$. The disks were acquired from Oxoid ${ }^{\mathrm{TM}}$ (Thermo Scientifics, Wilmington, USA).

Alpha-hemolytic, gray pointed colonies were obtained in 5\% sheep blood agar. The isolate was characterized as gram-positive cocci, negative for catalase and was identified as $A$. viridans using API 20 Strep.

Identification of $A$. viridans based solely on biochemical tests is complex as A. viridans has phenotypic and biochemical characteristics that are similar to those of other Aerococcus, leading to it being frequently misidentified as other bacteria 
when using conventional identification schemes (SENNEBY et al., 2013). To avoid misidentification, the bacterial species was confirmed using MALDITof MS (score > 2.).

This technique has been shown to be a valuable tool for the identification of gram-positive bacteria of clinical importance (CHRISTENSEN et al., 2012). Finally, in BLAST analysis, the isolate had higher than $98 \%$ identity of the $16 \mathrm{~S}$ rRNA gene with $A$. viridans strains isolated from a case of severe septicemia in human neonates in India (accession number Genbank MG576151.1), strains isolated from genitourinary tract infection in swine in Brazil (accession numbers KR819482.1 and KR819484.1), and from subclinical mastitis in cattle in China (accession number KM096431.1) (Figure 1). This is the first report of Aerococcus viridans associated with a clinical case of infection in a wild animal in a zoo. The veterinarians of the zoo performed a daily cleaning of the fistula with antiseptic products and application of repellent ointments for two weeks. After that treatment, the purulent vulvar secretion was not verified again.
The source of infection of Aerococcus species pathogenic for humans and animals is unknown. It has been isolated from different environments such as air, soil, milk, and invasive infections (CATTOIR et al., 2010; MOHAN et al., 2017; TOHNO et al., 2014). However, its distribution and epidemiology need to be elucidated. PEARCE et al. (2014) compared in a study the composition of the microbiota of women with and without symptoms of urinary incontinence and observed that the presence of bacteria of the genus Aerococcus spp. was more frequent in symptomatic patients. Although the mechanisms of virulence involved in infection are not well known, the presence of preexisting disease is a risk factor for invasion and colonization of the urinary tract by $A$. viridans (SHANNON et al., 2010). There are no data available regarding the occurrence of Aerococcus spp. in the microbiota of African and other elephant species, and the source of infection in the present case is unknown. The fistula in the genital tract created an external communication between reproductive system and urethra, a condition that probably contributed to $A$. viridans infection.

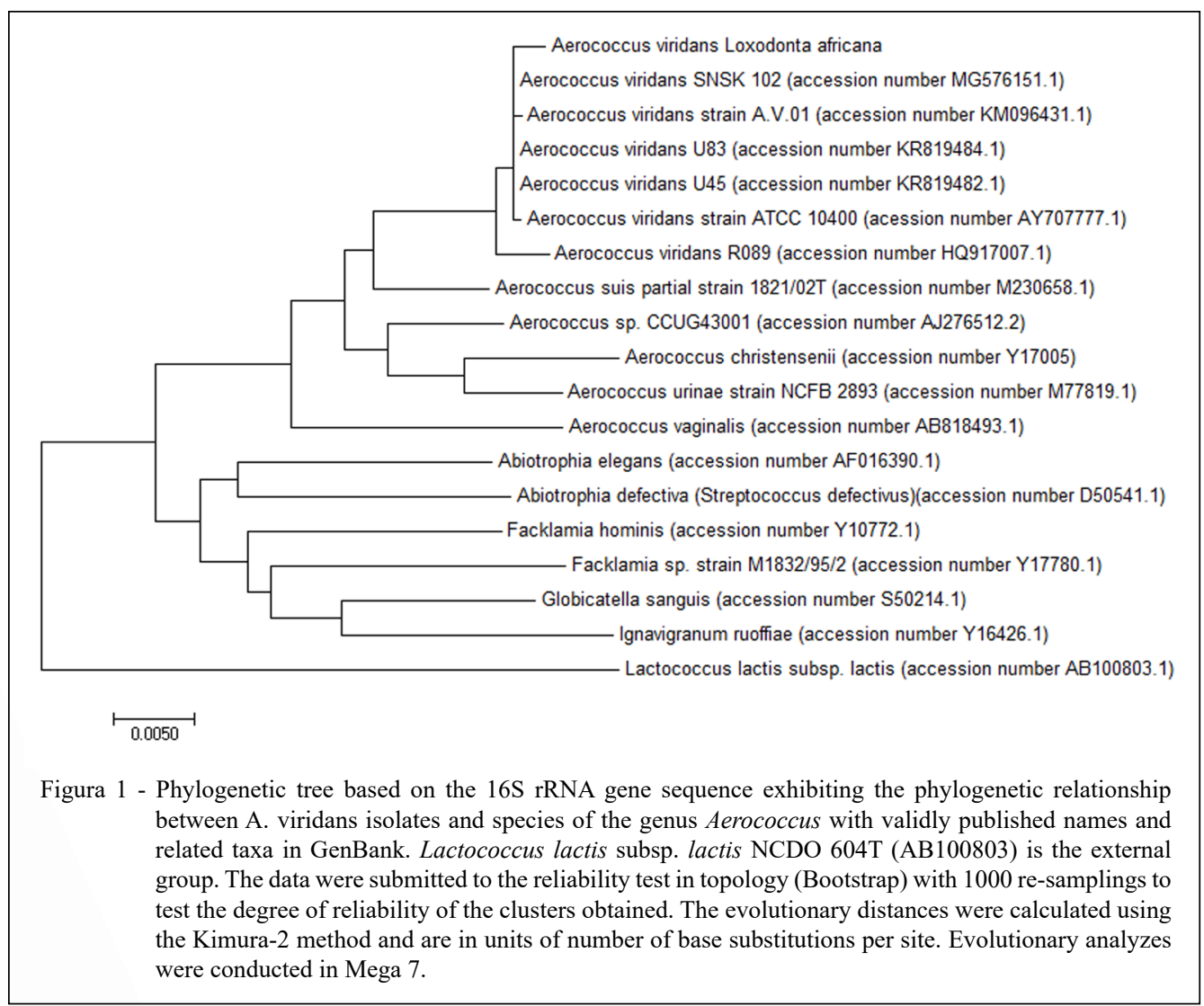

Ciência Rural, v.51, n.1, 2021. 
In the phylogenetic analysis, all strains of the genus Aerococcus clustered in a single branch. The elephant isolate grouped in a common cluster of species of $A$. viridans, and in a subgroup of pathogenic strains of humans and animals. High homology of the isolate from this study with pathogenic strains in other hosts reinforces the hypothesis of the pathogenic potential of the microorganism as a possible cause of the genitourinary tract infection in the female elephant.

The results of the antimicrobial susceptibility test revealed that the isolate presented resistance to ciprofloxacin and norfloxacin and sensitivity to the other antimicrobials evaluated. These results are consistent with the susceptibility pattern of strains for beta lactam antimicrobials isolated from humans and animals, as well vancomycin, similar to those described by MARTÍN et al. (2007) and MOHAN et al. (2017), although highly resistant strains have been reported in human bacteremic patients (UH et al., 2002). Recently there have been reports of changes in the susceptibility profile of species of the genus Aerococcus for the fluoroquinolones. Resistant strains have emerged in pictures of urinary infections in humans (CATTOIR et al.,2010; MOHAH et al., 2017).

Although the fluorquinolone class antimicrobials tested in this study are not recommended for veterinary use, the data obtained are relevant because they demonstrate the presence of resistance to a group of highest priority critically important antibiotics for humans (WHO, 2016). The phenomenon of bacterial resistance may be associated with the induction of selective pressure due to the prolonged and / or inappropriate use of antimicrobials in human and animal medicine. Greater dissemination and selection of this resistance may compromise the usefulness of a valuable class of antimicrobial agents in public health, reserved for severe cases of infection and also considered a class of choice in the treatment of genitourinary infections in humans (HOOPER, 2002).

This is the first report of Aerococcus viridans infection in the genital tract of a female African elephant. The genetic similarity with human and animal strains demonstrates that this emergent pathogen has a broad range of susceptible hosts.

\section{ACKNOWLEDGEMENTS}

This study was supported by Coordenação de Aperfeiçoamento de Pessoal de Nível Superior (CAPES), Brasil - Finance code 001, Conselho Nacional de Desenvolvimento Científico e Tecnológico (CNPq) (Grant nº301915/2018-0), Fundação de Amparo à Pesquisa do Estado de Minas Gerais (FAPEMIG) and Pró Reitoria de Pesquisa / Universidade Federal de Minas Gerais (PRPq/UFMG).

\section{DECLARATION OF CONFLICTS OF INTERESTS}

The authors declare no conflict of interest. The founding sponsors had no role in the design of the study; in the collection, analyses, or interpretation of data; in the writing of the manuscript, and in the decision to publish the results.

\section{AUTHORS' CONTRIBUTIONS}

The authors contributed equally to the manuscript.

\section{REFERENCES}

CATTOIR, V. et al. First molecular characterization of Fluoroquinolone Resistance in Aerococcus spp. Antimicrobial Agents and Chemotherapy. American Society for Microbiology. (55) 451-452, 2010. Available from: <http://dx.doi.org/10.1128/ aac.01065-10.>. Accessed: Mar. 10, 2020. doi: 10.1128/ AAC.01065-10.

CHRISTENSEN, J.J. et al. Matrix-assisted laser desorption ionization-time of flight mass spectrometry analysis of Grampositive, catalase-negative cocci not belonging to the Streptococcus or Enterococcus genus and benefits of database extension. Journal of Clinical Microbiology. 50(5):1787-1791, 2012. Avaible from: $<$ http://dx.doi.org/10.1128/jcm.06339-11>. Accessed: Mar. 10, 2020. doi: 10.1128/JCM.06339-11.

EUCAST [Internet]. The European Committee on Antimicrobial Susceptibility Testing. Breakpoint tables for interpretation of MICs and zone diameters. (9), 2019. [cited 2019 Jan 1] Available from: <www.eucast.org>. Accessed: Mar. 10, 2020.

FERREIRA, S.C.M. et al. Evidence of high exposure to Toxoplasma gondii in free-ranging and captive African carnivores. International Journal for Parasitology: Parasites and Wildlife. 24(8): 111-117, 2018. Available from: <https://doi.org/10.1016/j. ijppaw.2018.12.007>. Accessed: Mar. 10, 2020. doi: 10.1016/j. ijppaw.2018.12.007.

FOX, J.G. et al. Helicobacter bilis sp. nov., a novel Helicobacter isolated from bile, livers and intestines of aged, inbred mouse strains. Journal of Clinical Microbiology. 33: 445-454, 1995. Accessed: Mar. 10, 2020.

HALL, T.A. BioEdit: a user-friendly biological sequence alignment editor and analysis program for Windows 95/98/NT. Nucleic Acids Symposium Series. 41:95-98, 1999. Accessed: Mar, 10, 2020.

HOOPER, D.C. Fluoroquinolone resistance among Gram-positive cocci. The Lancet Infectious Diseases. 2(9):530-538, 2002. Available from: <http://dx.doi.org/10.1016/s1473-3099(02)003699>. Accessed: Mar. 10, 2020. doi: 10.1016/s1473-3099(02)00369-9.

KIMURA, M. A simple method for estimating evolutionary rates of base substitutions through comparative studies of nucleotide sequences. Journal of Molecular Evolution. 16(2):111-120, 1980. Available from: <http://dx.doi.org/10.1007/bf01731581>. Accessed: Mar. 10, 2020. doi: 10.1007/bf01731581.

KUMAR, S. et al. MEGA7: Molecular Evolutionary Genetics Analysis Version 7.0 for Bigger Datasets. Molecular Biology and Evolution. 33(7): 1870-1874, 2016. Available from: <http:// 
dx.doi.org/10.1093/molbev/msw054>. Accessed: Mar. 10, 2020. doi: 10.1093/molbev/msw054.

LEITE, A. et al. Aerococcus viridans urinary tract infection in a pediatric patient with secondary pseudohypoaldosteronism. Revista Argentina de Microbiología. Ciudad Autónoma de Buenos Aires. 42(4): 269-270, 2010. Available from: <https:// www.ncbi.nlm.nih.gov/pubmed/21229195>. Accessed: Mar. 10, 2020. doi: 10.1590/S0325-75412010000400005.

LIU, G. et al. Molecular and phenotypic characterization of Aerococcus viridans associated with subclinical bovine mastitis. PloS one. 28:10(4), 2015. Available from: <http://dx.doi. org/10.1371/journal.pone.0125001>. Accessed: Mar. 10, 2020. doi: 10.1371 journal.pone. 0125001

MARTÍN, V. et al. Characterization of Aerococcus viridans Isolates from Swine Clinical Specimens. Journal Of Clinical Microbiology. 45(9) 3053-3057, 2007. Available from: <http:// dx.doi.org/10.1128/JCM.00156-07>. Accessed: Mar. 10, 2020. doi: 1 10.1128/JCM.00156-07.

MOHAN, B. et al. Aerococcus Viridans: A rare pathogen causing Urinary Tract Infection. Journal of Clinical and Diagnostic Research. 11:01-03, 2017. Available from: <http://dx.doi.org/ 10.7860/JCDR/2017/23997.9229>. Accessed: Mar. 10, 2020. doi $10.7860 / \mathrm{JCDR} / 2017 / 23997.9229$

NATHAVITHARANA, K.A. et al. Acute meningitis in early childhood caused by Aerococcus viridans. British Medical Journal. 286:1248, 1983. Available from: <http://dx.doi. org/10.1136/bmj.286.6373.1248>. Accessed: Mar. 10, 2020. doi: 10.1136/bmj.286.6373.1248

PARREY, A.H. et al. Aerococcus viridans infection presenting as cutaneous vasculitis in an immunocompetent patient. Reumatologia. v.54, n.6, p.318-320, 2016. Avaible from: $<\mathrm{http}$ :/ dx.doi.org/ 10.5114/reum.2016.64909>. Accessed: Mar. 10, 2020 doi: $10.5114 /$ reum.2016.64909.

PEARCE, M.M. et al. The female urinary Microbiome: a Comparison of Women with and without Urgency Urinary Incontinence. Mbio. 5(4): 2-3, 2014. Available from: <http:// dx.doi.org/10.1128/mBio.01283-14.>. Accessed: Mar. 10, 2020. doi: $10.1128 / \mathrm{mBio} .01283-14$

PIEN, F.D. et al. Aerococcus viridans endocarditis. Mayo Clinic Proceedings. 59(1):47-48, 1984.

SAITOU, N. et al. The neighbor-joining method: a new method for reconstructing phylogenetic trees. Molecular Biology and Evolution. 4(4):406-425, 1987. Available from: <http://dx.doi.org/ 10.1016/s0025-6196(12)60342-5>. Accessed: Mar. 10, 2020. doi: $10.1016 / \mathrm{s} 0025-6196(12) 60342-5$.
SENNEBY, E. et al. Matrix-Assisted Laser Desorption IonizationTime of Flight Mass Spectrometry Is a Sensitive and Specific Method for Identification of aerococci. Journal of Clinical Microbiology. 51(4): 1303-1304, 2013. Available from: <http:// dx.doi.org/10.1128/JCM.02637-12>. Accessed: Mar. 10, 2020. doi: 10.1128/JCM.02637-12.

SHANNON, O. et al. Platelet Activation and Biofilm Formation by Aerococcus urinae, an Endocarditis-Causing Pathogen. Infection and Immunity. 78(10):4268-4275, 2010. Available from: <http:// dx.doi.org/10.1128/IAI.00469-10>. Accessed: Mar. 10, 2020. doi: 10.1128/IAI.00469-10.

TAYLOR, P.W. et al. Septic arthritis due to Aerococcus viridans. The Journal of Rheumatology. 12(5):1004-1005, 1985. Available from: < < <ttps://www.ncbi.nlm.nih.gov/pubmed/4087248.>. Accessed: Mar. 10, 2020.

THOMPSON, J.D. et al. CLUSTAL W: improving the sensitivity of progressive multiple sequence alignment through sequence weighting, position-specific gap penalties and weight matrix choice. Nucleic Acids Research. 22(22): 4673-4680, 1994. Available from: <http://dx.doi.org/10.1093/nar/22.22.4673>. Accessed: Mar. 10, 2020. doi: 10.1093/nar/22.22.4673

TOHNO, M. et al. Aerococcus vaginalis sp. nov., isolated from the vaginal mucosa of a beef cow, and emended descriptions of Aerococcus suis, Aerococcus viridans, Aerococcus urinaeequi, Aerococcus urinaehominis, Aerococcus urinae, Aerococcus christensenii and Aerococcus sanguinicola. International Journal of Systematic and Evolutionary Microbiology. 64(4): 1229-1236, 2014. Available from: <http://dx.doi.org/ 10.1099/ijs.0.058081-0>. Accessed: Mar. 10, 2020. doi: 10.1099/ijs.0.058081-0.

UH, Y. et al. Penicillin-resistant Aerococcus viridans bacteremia associated with granulocytopenia. Journal of Korean Medical Science. 17(1):113-115, 2002. Available from: <http://dx.doi. org/10.3346/jkms.2002.17.1.113>. Accessed: Mar. 10, 2020. doi: 10.3346/jkms.2002.17.1.113.

WHO Advisory Group on Integrated Surveillance of Antimicrobial Resistance (AGISAR). 2016. Critically Important Antimicrobials for Human Medicine, 4th revision. WHO, Geneva, Switzerland. Accessed: Mar. 10, 2020.

WILLIAMS, R.E. et al. Aerococcus, a new bacterial genus. J Gen Microbiol. 8: 475-480, 1953. Available from: <http://dx.doi. org/ 10.1099/00221287-8-3-475>. Accessed: Mar. 10, 2020. doi: $10.1099 / 00221287-8-3-475$.

YADAV, K. et al. Aortic pseudoaneurysm \&amp; endocarditis caused by Aerococcus viridans: A case report and literature review. Cardiovascular Revascularization Medicine. v.19, n.2, p.201-203, 2018. Available from: $<\mathrm{http} / / \mathrm{dx}$.doi.org/10.1016/j.carrev.2017.08.011>. Accessed: Mar. 10, 2020. doi: 10.1016/j.carrev.2017.08.011. 